Article

\title{
Fumigant Antifungal Activity of Myrtaceae Essential Oils and Constituents from Leptospermum petersonii against Three Aspergillus Species
}

\section{Eunae Kim and Il-Kwon Park *}

Division of Forest Insect Pests and Diseases, Korea Forest Research Institute, Seoul 130-712, Korea;

E-Mail:kea7013@gmail.com

* Author to whom correspondence should be addressed; E-Mail: parkik1@forest.go.kr;

Tel.: +82-2-961-2672; Fax: +82-2-961-2679.

Received: 11 July 2012; in revised form: 16 August 2012 / Accepted: 27 August 2012 /

Published: 3 September 2012

\begin{abstract}
Commercial plant essential oils obtained from 11 Myrtaceae plant species were tested for their fumigant antifungal activity against Aspergillus ochraceus, A. flavus, and A. niger. Essential oils extracted from Leptospermum petersonii at air concentrations of $56 \times 10^{-3} \mathrm{mg} / \mathrm{mL}$ and $28 \times 10^{-3} \mathrm{mg} / \mathrm{mL}$ completely inhibited the growth of the three Aspergillus species. However, at an air concentration of $14 \times 10^{-3} \mathrm{mg} / \mathrm{mL}$, inhibition rates of L. petersonii essential oils were reduced to $20.2 \%$ and $18.8 \%$ in the case of A. flavus and A. niger, respectively. The other Myrtaceae essential oils $\left(56 \times 10^{-3} \mathrm{mg} / \mathrm{mL}\right)$ only weakly inhibited the fungi or had no detectable affect. Gas chromatography-mass spectrometry analysis identified 16 compounds in L. petersonii essential oil. The antifungal activity of the identified compounds was tested individually by using standard or synthesized compounds. Of these, neral and geranial inhibited growth by $100 \%$, at an air concentration of $56 \times 10^{-3} \mathrm{mg} / \mathrm{mL}$, whereas the activity of citronellol was somewhat lover $(80 \%)$. The other compounds exhibited only moderate or weak antifungal activity. The antifungal activities of blends of constituents identified in L. petersonii oil indicated that neral and geranial were the major contributors to the fumigant and antifungal activities.
\end{abstract}

Keywords: antifungal activity; Myrtaceae essential oil; Leptospermum petersonii; Aspergillus ochraceus; Aspergillus flavus; Aspergillus niger 


\section{Introduction}

Aspergillus species are not only responsible for the spoilage of food and feed [1], but they also produce several toxins. Aflatoxins and ochratoxin A (OTA) are secondary metabolites produced by Aspergillus species, such as A. flavus, A. parasiticus, A. nomius, and A. ochraceus [2]. Aflatoxins are potent carcinogens for animals and humans [3]. OTA induces nephrotoxic, immunotoxic, teratogenic, and carcinogenic effects [4]. Plant essential oils are good candidates for the control of Aspergillus species, because they consist of many bioactive chemicals. Further, because the components of plant essential oils are highly volatile, they do not persist when used in fields or in water [5,6]. Many plant essential oils and their individual components have been reported to demonstrate antifungal activities against Aspergillus species [7-13]. The family Myrtaceae contains at least 3,000 species within 130-150 genera, and it is distributed in several tropical and warm-temperature areas. Many essential oils produced by these species exhibit insecticidal, antifungal, or nematicidal activity [6,14-16]. The pesticidal activity of Eucalyptus essential oils have been greatly reviewed by Batish et al. [17]. Furthermore, essential oils from Myrtaceae have multiple uses, i.e., in perfumery, pharmaceutical, and in other industries [18]. Because of their many advantages described above, we assessed the fumigant antifungal activities of 11 Myrtaceae plant essential oils and their components against three Aspergillus fungi species with the goal of discovering new and safe alternatives for controlling the growth of Aspergillus species.

\section{Results and Discussion}

\subsection{Fumigant Antifungal Activity of Plant Essential Oils}

The abilities of 11 Myrtaceae essential oils to inhibit the growth of three Aspergillus species are shown in Table 1. The essential oils produced by Leptospermum petersonii inhibited growth by $100 \%$ at air concentrations of $56 \times 10^{-3} \mathrm{mg} / \mathrm{mL}$ and $28 \times 10^{-3} \mathrm{mg} / \mathrm{mL}$. However, at an air concentration of $14 \times 10^{-3} \mathrm{mg} / \mathrm{mL}$, inhibition rates of $L$. petersonii essential oils were reduced to $20.2 \%$ and $18.8 \%$ against A. flavus and A. niger, respectively. Inhibition rates of essential oils extracted from Eucalyptus globulus, Melaleuca dissitiflora, and M. quinquenervia at an air concentration of $56 \times 10^{-3} \mathrm{mg} / \mathrm{mL}$ against A. ochraceus were 26.1, 21.5, and 26.5\%, respectively, and essential oils from $M$. dissitiflora and M. quinquenervia inhibited the growth of $A$. flavus by $22.9 \%$ and $34.45 \%$, respectively at the same air concentration. None of the other Myrtaceae essential oils showed antifungal activity against either of the three Aspergillus species at an air concentration of $56 \times 10^{-3} \mathrm{mg} / \mathrm{mL}$. In the study, only L. petersonii essential oils demonstrated strong antifungal activities against the three Aspergillus species. The antifungal activities of Myrtaceae plant essential oils [19-22], including those of L. petersonii essential oils and constituents have been reported previously [23,24]. Park et al. [25] reported that essential oils and major constituents extracted from L. petersonii such as citronellal, neral, and geranial show antifungal activity against various dermatophytes, such as Microsporum canis, Trichophyton mentagrophytes, and Microsporum gypseum. 
Table 1. Fumigant antifungal activities of 11 Myrtaceae essential oils against three Aspergillus species.

\begin{tabular}{ccccc}
\hline \multirow{2}{*}{ Plant species } & Conc. & \multicolumn{2}{c}{ Inhibition rate (Mean \pm S.E., $\%)$} \\
\cline { 3 - 5 } & $\times \mathbf{1 0}^{-3} \mathbf{~} \mathbf{m g} \mathbf{m L}$ air & $\begin{array}{c}\text { Aspergillus } \\
\text { ochraceus }\end{array}$ & $\begin{array}{c}\text { Aspergillus } \\
\text { flavus }\end{array}$ & $\begin{array}{c}\text { Aspergillus } \\
\text { niger }\end{array}$ \\
\hline Eucalyptus citriodora & 56 & $0 \mathrm{~d}^{1}$ & $23.5 \pm 2.6 \mathrm{c}$ & $0 \mathrm{c}$ \\
Eucalyptus polybractea & 56 & $0 \mathrm{~d}$ & $0 \mathrm{~d}$ & $0 \mathrm{c}$ \\
Eucalyptus smithii & 56 & $0 \mathrm{~d}$ & $0 \mathrm{~d}$ & $0 \mathrm{c}$ \\
Eucalyptus radiata & 56 & $0 \mathrm{~d}$ & $0 \mathrm{~d}$ & $0 \mathrm{c}$ \\
Eucalyptus dives & 56 & $0 \mathrm{~d}$ & $0 \mathrm{~d}$ & $0 \mathrm{c}$ \\
Eucalyptus globulus & 56 & $26.1 \pm 0.4 \mathrm{~b}$ & $0 \mathrm{~d}$ & $0 \mathrm{c}$ \\
Melaleuca dissitiflora & 56 & $21.5 \pm 0.6 \mathrm{c}$ & $22.9 \pm 1.9 \mathrm{c}$ & $0 \mathrm{c}$ \\
Melaleuca quinquenervia & 56 & $26.5 \pm 0.4 \mathrm{~b}$ & $34.4 \pm 7.0 \mathrm{~b}$ & $0 \mathrm{c}$ \\
Melaleuca uncinata & 56 & $0 \mathrm{~d}$ & $0 \mathrm{~d}$ & $0 \mathrm{c}$ \\
Melaleuca linariifolia & 56 & $0 \mathrm{~d}$ & $0 \mathrm{~d}$ & $0 \mathrm{c}$ \\
Leptospermum petersonii & 56 & $100 \mathrm{a}$ & $100 \mathrm{a}$ & $100 \mathrm{a}$ \\
& 28 & $100 \mathrm{a}$ & $100 \mathrm{a}$ & $100 \mathrm{a}$ \\
& 14 & $0 \mathrm{~d}$ & $20.2 \pm 4.3 \mathrm{c}$ & $18.8 \pm 13.4 \mathrm{~b}$ \\
& & $\mathrm{~F}_{13,42}=0.25$ & $\mathrm{~F}_{13,42}=5.68$ & $\mathrm{~F}_{13,42}=12.84$ \\
& $p<0.0001$ & $p<0.0001$ & $p<0.0001$ \\
\hline
\end{tabular}

\footnotetext{
${ }^{1}$ Mean values within a column followed by same letters are not significantly different (Scheffe's test).
}

\subsection{Chemical Components of Plant Essential Oils}

The chemical components of $L$. petersonii are described in our previous study [15] and are listed in Table 2. Geranial (29.91\%) and neral (22.83\%) were the major constituents of L. petersonii oils, followed by citronellal (16.72\%), isopulegol (5.20\%), and linalool (3.25\%). Seasonal variation in the chemical composition of Leptospermum oils has been described by Demuner et al. [26]. They report that geranial, neral, and citronellal were the major components of L. petersonii grown in Brazil, similar to our result. They also reported the difference in abundance of each chemical according to harvest season. The abundances of neral and geranial were higher during rainy season than those during dry season. This indicates that the essential oil of $L$. petersonii harvested in rainy season is a better source for isolating antifungals.

The chemical compositions of other Eucalyptus oils are well characterized $[6,15,27]$. The main components of Eucalyptus oils tested in our study were 1,8-cineole, citronellal, $\alpha$-pinene, $p$-cymene, limonene, and $\alpha$-terpineol, none of which exhibited detectable antifungal activity. This explains why essential oils extracted from Eucalyptus species do not show antifungal activity against Aspergillus species. The chemical compositions of Melaleuca quinquenerivia, M. dissitiflora, M. linariifolia, and M. uncinata oils have been determined by Lee et al. [15] and Yeom [27], and the major constituents include terpinen-4-ol, 1,8-cineole, limonene, $E$-nerolidol, isopulegol, $\alpha$-terpineol, linalool, and $p$-cymene. Most of these compounds did not show antifungal activity against Aspergillus species in this study. Chemical composition of essential oils extracted from Eucalyptus and Melaleuca species explain the reason for the weak or absence of antifungal activity against Aspergillus species in this study. Essential oils such as those isolated from Melissa officinalis, Lippia alba, Litsea cubeba, and 
Cymbopogon citratus contain neral and geranial as main components; therefore, we considered them as good candidates for controlling Aspergillus species [28-31].

Table 2. Chemical composition of Leptospermum petersonii essential oil ${ }^{1}$.

\begin{tabular}{ccccc}
\hline \multirow{2}{*}{ No. } & Compounds & \multicolumn{2}{c}{ RI $^{2}$} & \multirow{2}{*}{ Amount (w/w, \%) } \\
\cline { 3 - 4 } 1 & $\alpha$-Pinene & 928 & 1014 & 0.54 \\
2 & 6-Methyl-5-heptene-2-one & 964 & 1330 & 0.77 \\
3 & $\beta$-Pinene & 967 & 1098 & 0.24 \\
4 & $\beta$-Myrcene & 981 & 1155 & 1.26 \\
5 & $p$-Cymene & 1012 & 1261 & 0.07 \\
6 & 1,8 -Cineole & 1018 & 1196 & 0.09 \\
7 & Limonene & 1020 & 1189 & 0.11 \\
8 & Linalool & 1084 & 1536 & 3.25 \\
9 & Isopulegol & 1128 & 1559 & 5.20 \\
10 & Citronellal & 1131 & 1470 & 16.72 \\
11 & Citronellol & 1211 & 1753 & 6.00 \\
12 & Neral & 1216 & 1670 & 22.83 \\
13 & Geraniol & 1236 & 1834 & 3.63 \\
14 & Geranial & 1245 & 1721 & 29.91 \\
15 & $\beta$-Caryophyllene & 1414 & 1583 & 0.14 \\
16 & Aromadendrene & 1435 & 1597 & 0.08 \\
& Sum of identified compounds & & & 90.85 \\
\hline
\end{tabular}

${ }^{1}$ Chemical components of L. peterisonii have already been reported in our previous study [15];

${ }^{2}$ Retention indices of plant essential oils; Components were identified by co-injection with authentic standard on 2 columns.

\subsection{Antifungal Activities of Individual Compounds}

The fumigant antifungal activities of compounds identified in L. petersonii are shown in Table 3 . The activity varied per the test compounds and the dose. The growth of $A$. ochraceus, was completely inhibited by neral and geranial at air concentrations of $56 \times 10^{-3}$ and $28 \times 10^{-3} \mathrm{mg} / \mathrm{mL}$. The fumigant antifungal activity of neral remained at $100 \%$ at an air concentration of $14 \times 10^{-3} \mathrm{mg} / \mathrm{mL}$, but was reduced to $34.1 \%$ at $7 \times 10^{-3} \mathrm{mg} / \mathrm{mL}$. In contrast, the inhibition rate of geranial at an air concentration of $14 \times 10^{-3} \mathrm{mg} / \mathrm{mL}$ was $20.1 \%$. The inhibition rate of citronellol against $A$. ochraceus was $83.7 \%$ at an air concentration of $56 \times 10^{-3} \mathrm{mg} / \mathrm{mL}$, but was reduced to $29.4 \%$ at an air concentration of $28 \times 10^{-3} \mathrm{mg} / \mathrm{mL}$. Geraniol inhibited the growth of $A$. ochraceus by $64.6 \%$ and $38.4 \%$ at air concentration of $56 \times 10^{-3}$ and $28 \times 10^{-3} \mathrm{mg} / \mathrm{mL}$, respectively. The other compounds tested were inhibitory at rates less than $50 \%$. 
Table 3. Fumigant antifungal activity of compounds identified in Leptospermum petersonii essential oils against three Aspergillus species.

\begin{tabular}{|c|c|c|c|c|}
\hline \multirow[b]{2}{*}{ Compounds } & \multirow{2}{*}{$\begin{array}{c}\text { Conc., } \\
\times 10^{-3} \mathrm{mg} / \mathrm{mL} \text { air }\end{array}$} & \multicolumn{3}{|c|}{ Inhibition rate (Mean \pm S.E., \%) } \\
\hline & & $\begin{array}{c}\text { Aspergillus } \\
\text { ochraceus }\end{array}$ & $\begin{array}{l}\text { Aspergillus } \\
\text { flavus }\end{array}$ & $\begin{array}{c}\text { Aspergillus } \\
\text { niger }\end{array}$ \\
\hline$\alpha$-Pinene & 56 & $0 \mathrm{f}^{1}$ & $0 \mathrm{~d}$ & $0 \mathrm{e}$ \\
\hline 6-Methyl-5-heptene-2-one & 56 & Of & $0 \mathrm{~d}$ & $0 \mathrm{e}$ \\
\hline$\beta$-Pinene & 56 & Of & $0 \mathrm{~d}$ & $0 \mathrm{e}$ \\
\hline$\beta$-Myrcene & 56 & of & $0 \mathrm{~d}$ & $0 \mathrm{e}$ \\
\hline$p$-Cymene & 56 & of & $0 \mathrm{~d}$ & $0 \mathrm{e}$ \\
\hline 1,8-Cineole & 56 & of & $0 \mathrm{~d}$ & $0 \mathrm{e}$ \\
\hline Limonene & 56 & Of & $0 \mathrm{~d}$ & $0 \mathrm{e}$ \\
\hline Linalool & 56 & $36.6 \pm 0.8 \mathrm{~d}$ & $0 \mathrm{~d}$ & $0 \mathrm{e}$ \\
\hline Isopulegol & 56 & $34.6 \pm 3.2 \mathrm{~d}$ & od & $33.4 \pm 2.2 \mathrm{~cd}$ \\
\hline Citronellal & 56 & of & $0 \mathrm{~d}$ & $16.2 \pm 11.8 \mathrm{de}$ \\
\hline \multirow[t]{2}{*}{ Citronellol } & 56 & $83.7 \pm 3.3 b$ & $90 \pm 0.7 \mathrm{a}$ & $81.1 \pm 9.0 \mathrm{~b}$ \\
\hline & 28 & $29.4 \pm 3.0 \mathrm{de}$ & $37.7 \pm 4.1 b$ & $35.3 \pm 7.0 \mathrm{c}$ \\
\hline \multirow[t]{4}{*}{ Neral } & 56 & $100 \mathrm{a}$ & $100 \mathrm{a}$ & $100 \mathrm{a}$ \\
\hline & 28 & $100 \mathrm{a}$ & $26.9 \pm 2.1 b c$ & $0 \mathrm{e}$ \\
\hline & 14 & $100 \mathrm{a}$ & -2 & - \\
\hline & 7 & $34.1 \pm 4.2 \mathrm{~d}$ & - & - \\
\hline \multirow[t]{2}{*}{ Geraniol } & 56 & $64.6 \pm 7.5 \mathrm{c}$ & $36.7 \pm 11.3 b$ & $77.1 \pm 9.8 b$ \\
\hline & 28 & $38.4 \pm 4.4 \mathrm{~d}$ & - & $0 \mathrm{e}$ \\
\hline \multirow[t]{3}{*}{ Geranial } & 56 & $100 \mathrm{a}$ & $100 \mathrm{a}$ & $100 \mathrm{a}$ \\
\hline & 28 & $100 \mathrm{a}$ & $29.8 \pm 3.3 b c$ & $0 \mathrm{e}$ \\
\hline & 14 & $20.1 \pm 3.8 \mathrm{e}$ & $22.3 \pm 3.5 c$ & - \\
\hline$\beta$-Caryophyllene & 56 & of & $0 \mathrm{~d}$ & $0 \mathrm{e}$ \\
\hline \multirow[t]{3}{*}{ Aromadendrene } & 56 & of & od & $0 \mathrm{e}$ \\
\hline & & $F_{22,69}=6.14$ & $F_{19,60}=8.77$ & $\mathrm{~F}_{19,60}=18.71$ \\
\hline & & $p<0.0001$ & $p<0.0001$ & $p<0.0001$ \\
\hline
\end{tabular}

\footnotetext{
${ }^{1}$ Means values within a column followed by same letters are not significantly different (Sheffe's test); ${ }^{2}$ Not tested.
}

Neral, geranial, and citronellol inhibited the growth of $A$. flavus by $>90 \%$ at an air concentration of $56 \times 10^{-3} \mathrm{mg} / \mathrm{mL}$, but only reached $40 \%$ at $28 \times 10^{-3} \mathrm{mg} / \mathrm{mL}$. Other compounds showed only weak or no inhibition against A. flavus. Neral, geranial, citronellol, and geraniol inhibited the growth of A. niger by $100 \%, 100 \%, 81.1 \%$, and $77.1 \%$, respectively, at concentration of $56 \times 10^{-3} \mathrm{mg} / \mathrm{mL}$, whereas only weak or no inhibition was at a concentration of $28 \times 10^{-3} \mathrm{mg} / \mathrm{mL}$. Other compounds exhibited either weak or no antifungal activity against $A$. niger at an air concentration of $56 \times 10^{-3} \mathrm{mg} / \mathrm{mL}$. Lee et al. [15] and Park et al. [25] have reported the bioactivity of geranial and neral compounds against phytopathogens and dermatophytes. Shukla et al. [32] also reported the antifungal activity of neral and geranial against Aspergillus flavus. Citronellol [33] along with citral, citronellal, citronellol, and geraniol also inhibits the growth of $A$. flavus. The findings of Setzer et al. [34] that a mixture of neral and geranial potently inhibits the growth of $A$. niger agrees with the results of our present study, except that we were unable to demonstrate that citronellal was inhibitory. Furthermore, citronellol and 
geraniol were potent inhibitors of the growth of $A$. niger. The difference might be attributed to differences in the bioassay methods used. Here, we used a fumigant assay, not one that involves more direct contact as in the studies cited.

Structure-activity relationships of certain phytochemicals obtained from plant essential oils against fungi have been well studied. Antifungal activities of unsaturated aldehydes (citral, cinnamic aldehyde, and citronellal) and an unsaturated alcohol (geraniol) are stronger than those of hydrocarbons, such as camphene, limonene, and $\alpha$-terpinene against A. niger, Fusarium oxysporum, and Penicillium digitatum [35]. The studies of Lee et al. [15] demonstrate that aldehydes and alcohols are generally more toxic than hydrocarbons for three plant pathogens, namely, Phytophthora cactorum, Cryphonectria parasitica, and Fusarium circinatum. The results of our present study are consistent with their findings. Thus, aldehydes (neral, geranial) and alcohols (citronellol, geraniol) were more effective antifungals against the three Aspergillus species than were hydrocarbons, such as $\alpha$-pinene, 6-methyl-5-heptene-2-one, $\beta$-pinene, $\beta$-myrcene, $p$-cymene, limonene, and $\beta$-caryophyllene. Further, there were significant differences in the antifungal activities among chemicals possessing the same functional group. For example, inhibitory activities of primary alcohol groups, such as present in citronellol and geraniol, were greater than those of secondary (isopulegol) and tertiary alcohols (linalool). This result indicates that the position of the hydroxyl group is related to the antifungal activity and is consistent with the results of our previous research [15]. For aldehydes, the antifungal activity of neral and geranial was very strong, but citronellal demonstrated either very weak or no detectable inhibition of the growth of the three Aspergillus species. The studies of Moleyar and Narasimham [35] and Lee et al. [15] demonstrate that $\alpha, \beta$-unsaturated carbonyl compounds, in which carbonyl group is conjugated with an alkene, demonstrate strong antifungal activity. Such compounds include neral and geranial.

\subsection{Antifungal Activity of Artificial Blends}

Elimination assays of $L$. petersonii oils indicated that the omission of neral and geranial from the artificial mixture resulted in a significant decrease in the fumigant antifungal activities of the blend $\left(\mathrm{F}_{16,51}=1.158, p<0.0001\right.$; Figure 1$)$. These results indicate that neral and geranial are major contributors to the fumigant antifungal activity of $L$. petersonii oil and that they act synergistically with respect to their antifungal activity against A. flavus. Omission of other compounds from the artificial mixture did not cause a significant difference in the fumigant toxicity of the blend. Jiang et al. [36] have suggested that chemicals that protect plants against fungal infections are more effective when they contain compounds that act by different mechanisms.

\section{Experimental}

\subsection{Fungal Strains and Culture Conditions}

The three Aspergillus species (Aspergillus ochraceus, A. niger, and A. flavus) used in this study were supplied by KACC (Korean Agricultural Culture Collection, Suwon city, Korea). They were routinely maintained on malt extract agar (MEA) at $28^{\circ} \mathrm{C}$. 


\subsection{Essential Oils and Chemicals}

Essential oils of Eucalyptus citriodora, E. smithii, E. globulus, E. radiata, E. dives, E. polybractea, M. dissitiflora, M. quinquenervia, M. uncinata, M. linariifolia, and L. petersonii were purchased from G.R. Davis Pty. Ltd. (Riverstone NSW 2765, Australia). Isopulegol (purity, 99\%), 1,8-cineole (purity, 99\%), (+)-limonene (purity, 97\%), citronellol (purity, 95\%), citronellal (purity, 85\%) and myrcene (purity, 95\%) were purchased from Sigma-Aldrich (Milwaukee, WI, USA). Geraniol (purity, 96\%), aromadendrene (purity, 97\%), and $p$-cymene (purity, 95\%) were purchased from Fluka (Buchs, Switzerland). $\alpha$-Pinene (purity, 95\%), $\beta$-caryophyllene (purity, 90\%), and $\beta$-pinene (purity, 94\%) were purchased from Tokyo Kasei (Tokyo, Japan), and linalool (purity, 98\%) was purchased from Wako Pure Chemical Industries Ltd. (Osaka, Japan). The synthesis of 6-methyl-5-hepten-2-one, geranial, and neral was performed according to our published method [15].

\subsection{Chemical Analysis of L. petersonii Oil}

The chemical analysis of $L$. petersonii plant essential oils was performed according to our published method [15].

\subsection{Antifungal Activity of Oils and Individual Compounds}

Antifungal activities were determined following the methods of Lee et al. [15]. MEA (malt extract agar, Difco, Sparks, MD, USA) plates were prepared using plastic Petri dishes $(87 \mathrm{~mm})$. Each agar-mycelial plug (diameter, $7 \mathrm{~mm}$ ) of A. ochraceus, A. niger, and A. flavus were inoculated into the center of the Petri dish. Lids were placed upside down on the Petri dishes. Essential oils or their constituents were introduced onto a paper disc ( $8 \mathrm{~mm}$, Advantec, Tokyo, Japan), which was placed on the agar-free lid of the Petri dish. Petri dishes were sealed with parafilm to prevent the leaking of test oils and compounds. After inoculation, the plates were incubated at $28{ }^{\circ} \mathrm{C}$ in the dark. Colony diameter was measured after growth in the control treatment had completely covered the Petri dishes (average, 16-17 days for A. ochraceus, 14 days for A. niger, and 10-11 days for A. flavus). All treatments were replicated 4 times. The percent difference of growth inhibition between the treatment and control groups were calculated using the following formula:

$$
\% \text { Inhibition }=\mathrm{C}-\mathrm{T} / \mathrm{C} \times 100
$$

where $\mathrm{C}$ is an average of the four replicates of hyphal extension $(\mathrm{mm})$ in control plates, and $\mathrm{T}$ is an average of 4 replicates of hyphal extension $(\mathrm{mm})$ of plates treated with essential oils, an individual compound, and or artificial blends of L. petersonii constituents.

\subsection{Antifungal Activity of Artificial Blends}

To determine the contribution of each constituent of essential oil to the inhibition of growth of A. flavus, we prepared blends of all constituents for L. petersonii oil that mimicked the natural oil. We also prepared a number of blends, each lacking one constituent (Figure 1). Blends were based on the natural composition of the L. petersonii oil, as indicated by GC-FID (Table 2). The concentration of L. petersonii was $28 \times 10^{-3} \mathrm{mg} / \mathrm{mL}$. The concentration of the complete mixture of $L$. peterisonii oil 
was $25.43 \times 10^{-3} \mathrm{mg} / \mathrm{mL}$. The concentrations of other blends were determined by omitting each constituent equivalent to the ratio identified in the L. petersonii oil.

Figure 1. Fumigant antifungal activity of the oil, full mixture, and selected blends of the constituents of L. petersonii essential oil against Aspergillus flavus. The air concentration of L. peterisonii was $28 \times 10^{-3} \mathrm{mg} / \mathrm{mL}$. The air concentration of the full mixture of L. peterisonii oil was $25.43 \times 10^{-3} \mathrm{mg} / \mathrm{mL}$. The concentrations of other blends were determined by removing each constituent equivalent to the ratio identified in L. peterisonii oil. Mean values corresponding to each treatment with different letters are significantly different from each other $\left(\mathrm{F}_{16,51}=1.158, p<0.0001\right.$, Scheffe's test $)$.

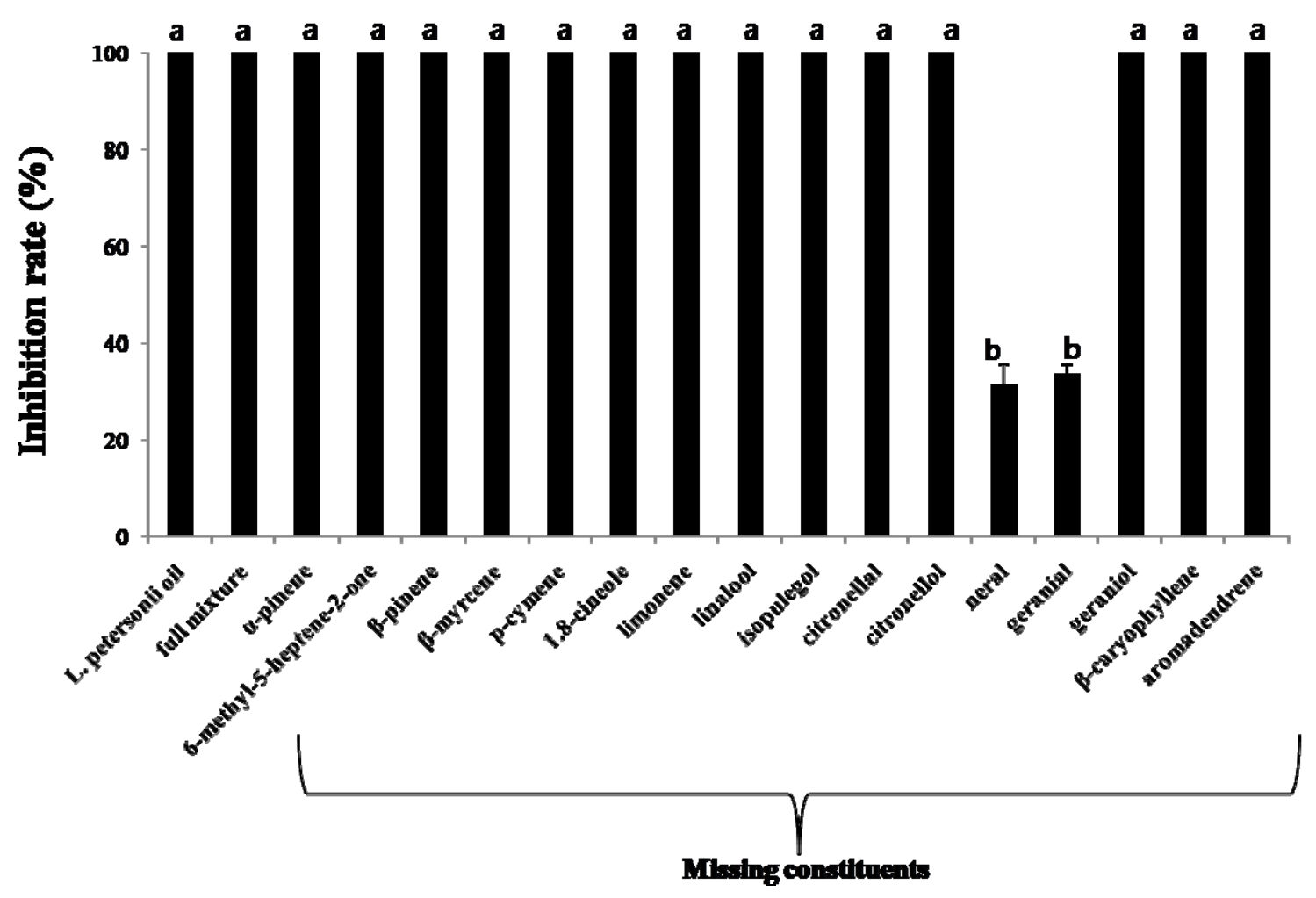

\subsection{Stastistical Analysis}

Mortality was converted to the arcsine square root values for analysis of variance (ANOVA). Treatment means were compared and contrasted by Scheffe's test [37].

\section{Conclusions}

Our results indicate that the essential oil and certain of its constituents extracted from L. petersonii oil could be useful for inhibiting the growth of three Aspergillus species. However, further research is necessary for determining the practical applicability of L. petersonii oil and its constituents as novel fungicides, to determine its safety for humans, for developing formulations to improve its activity and stability, and to reduce treatment costs. 


\section{References}

1. Abarc, M.L.; Bragulat, M.R.; Castella, G.; Cabanes, F.J. Mycoflora and aflatoxin-producing strains in animal mixed feeds. J. Food. Protect. 1994, 57, 256-258.

2. Fente, C.A.; Jaimez, O.J.; Vizquez, B.I.; Franco, C.M.; Cepeda, A. A new additive for culture media for rapid determination of aflatoxin-producing Aspergillus strains. Appl. Environ. Microbiol. 2001, 67, 4858-4862.

3. Dvorackova, I. Aflatoxins and Human Health; CRC Press: Boca Raton, FL, USA, 1990; p. 154.

4. Höhler, D. Ochratoxin A in food and feed: Occurrence, legislation and mode of action. Z. Ernährungswiss. 1998, 37, 2-12.

5. Park, I.K.; Choi, K.S.; Kim, D.H.; Choi, I.H.; Kim, L.S.; Bak, W.C.; Choi, J.W.; Shin, S.C. Fumigant activity of plant essential oils and components from horseradish, anise and garlic oils against Lycoriella ingenua (Diptera: Sciaridae). Pest Manag. Sci. 2006, 62, 723-728.

6. Park, H.M.; Kim, J.; Chang, K.S.; Kim, B.S.; Yang, Y.J.; Kim, G.H.; Shin, S.C.; Park, I.K. Larvicidal activity of Myrtaceae essential oils and their components against Aedes aetypti, acute toxicity on Daphnia magna, and aqueous residue. J. Med. Entomol. 2011, 48, 405-410.

7. Varma, J.; Dubey, N.K. Efficacy of essential oils of Caesulia axillaris and Mentha arvensis against some storage pests causing biodeterioration of food commodities. Int. J. Food Microbiol. 2001, 68, 207-210.

8. Soliman, K.M.; Badeaa, R.I. Effect of oil extracted from some medicinal plants on different mycotoxigenic fungi. Food Chem. Toxicol. 2002, 40, 1669-1675.

9. Nguefack, J.; Leth, V.; Amvam Zollo, P.H.; Mathur, S.B. Evaluation of five essential oils from aromatic plants of Cameroon for controlling food spoilage and mycotoxin producing fungi. Inter. J. Food Microbiol. 2004, 94, 329-334.

10. Rassoli, I.; Abyaneh, M.R. Inhibitory effects of thyme oils on growth and aflatoxin production by Aspergillus parasiticus. Food Control 2004, 15, 479-483.

11. Gowda, N.K.S.; Malathi, V.; Suganthi, R.U. Effect of some chemical and herbal compounds on growth of Aspergillus parasiticus and aflatoxin production. Anim. Feed Sci. Technol. 2004, 116, 281-291.

12. Rasooli, I.; Owlia, P. Chemoprevention by thyme oils of Aspergillus parasiticus growth and aflatoxin production. Phytochemistry 2005, 66, 2851-2856.

13. Rasooli, I.; Rezaei, M.B.; Allameh, A. Growth inhibition and morphological alternations of Aspergillus niger by essential oils from Thymus eriocalyx and Thymus x-porlock. Food Control 2006, 17, 359-364.

14. Lee, B.H.; Annis, P.C.; Tumaalii, F.; Choi, W.S. Fumigant toxicity of essential oils from the Myrtaceae family and 1,8-cineole against 3 major stored-grain insects. J. Stored Prod. Res. 2004, $40,553-564$.

15. Lee, Y.S.; Kim, J.; Shin, S.C.; Lee, S.G.; Park, I.K. Antifungal activity of Myrtaceae essential oils and their components against three phytopathogenic fungi. Flavour Frag. J. 2008, 23, 23-28.

16. Park, I.K.; Park, J.Y.; Kim, K.H.; Choi, K.S.; Choi, I.H.; Kim, C.S.; Shin, S.C. Nematicidal activity of plant essential oils and components from garlic (Allium sativum) and cinnamon (Cinnamomum verum) oils against the pinewood nematode (Bursaphelenchus xylophilus). Nematology 2005, 7, 767-774. 
17. Batish, D.R.; Singh, H.P.; Kohli, R.K.; Kaur, S. Eucalyptus essential oil as a natural pesticide. For. Ecol. Manag. 2008, 256, 2166-2174.

18. Boland, D.J.; Brophy, J.J.; House, A.P.N. Eucalyptus Leaf Oils: Use, Chemistry, Distillation and Marketing; Inkata Press: Melbourne/Sydney, Australia, 1991; p. 252.

19. Faouzia, H.; Souad, F.T.; Tantaoui-Elaraki, A. Antimicrobial activity of twenty-one Eucalyptus essential oils. Fitoterapia 1993, 64, 71-77.

20. Su, Y.C.; Ho, C.L.; Wang, E.I.-C.; Chang, S.T. Antifungal activities and chemical compositions of essential oils from leaves of four eucalypts. Taiwan J. For. Sci. 2006, 21, 49-61.

21. Carson, C.F.; Riley, T.V. Antimicrobial activity of the major components of the essential oil of Melaleuca alternifolia. J. Appl. Bacteriol. 1995, 78, 264-269.

22. Ramezani, H.; Singh, H.P.; Batish, D.R.; Kohli, R.K. Antifungal activity of the volatile oil of Eucalyptus citriodora. Fitoterapia 2002, 73, 261-262.

23. Hood, J.R.; Burton, D.; Wilkinson, J.M.; Cavanagh, H.M.A. Antifungal activity of Leptospermum petersonii oil volatiles against Aspergillus spp. in vitro and in vivo. J. Antimicrob. Chemother. 2010a, 65, 285-288.

24. Hood, J.R.; Burton, D.M.; Wilkinson, J.M.; Cavanagh, H.M.A. The effect of Leptospermum petersonii essential oil on Candida albicans and Aspergillus fumigates. Med. Mycol. 2010b, 48, 922-931.

25. Park, M.J.; Gwak, K.S.; Yang, I.; Choi, W.S.; Jo, H.J.; Chang, J.W.; Jeung, E.B.; Choi, I.G. Antifungal activities of the essential oils in Syzygium aromaticum (L.) Merr. Et Perry and Leptospermum petersonii Bailey and their constituents against various dermatophytes. J. Microbiol. 2007, 45, 460-465.

26. Demuner, A.J.; Barbosa, L.C.A.; Magalhaes, C.G.; Silva, C.J.; Maltha, C.R.A.; Pinheiro, A.L. Seasonal variation in the chemical composition and antimicrobial activity of volatile oils of three species of Leptospermum (Myrtaceae) grown in Brazil. Molecules 2011, 16, 1181-1191.

27. Yeom, H.J. Fumigant and contact toxicity of plant essential oils and their components against German cockroach, Blattella germanica L. M.S. Dissertation, Chungbuk National University, Cheongju, Korea, 2012.

28. Azar, P.A.; Poraham-Darvasari, A.; Sharifan, A.; Saber-Tehrani, M.; Soleimani, A. Antibacterial activity and chemical constitutions of Melissa officinalis L. Asian J. Chem. 2011, 3, 1381-1383.

29. López, M.A.; Stashenko, E.E.; Fuentes, J.L. Chemical and antigenotoxic properties of Lippia alba essential oils. Genet. Mol. Biol. 2011, 34, 479-488.

30. Si, L.; Chen, Y.; Han, X.; Zhan, Z.; Tian, S.; Cui, Q.; Wang, Y. Chemical composition of essential oils of Litsea cubeba harvested from its distribution areas in China. Molecules 2012, 17, 7057-7066.

31. Barbosa, L.C.A.; Pereira, U.A.; Martinazzo, A.P.; Maltha, C.R.Á.; Teixeira, R.R.; de Castro Melo, E. Evaluation of the chemical composition of Brazilian commercial Cymbopogon citratus (D.C.) Stapf samples. Molecules 2008, 13, 1864-1874.

32. Shukla, R.; Kumar, A.; Singh, P.; Dubey, N.K. Efficcy of Lippia alba (Mill.) Brown essential oil and its monoterpene aldehyde constituents against fungi isolated from some edible legume seeds and alfatoxin B1 production. Int. J. Food Microbiol. 2009, 135, 165-170.

33. Mahmoud, A.L. Antifungal action and antiaflatoxigenic properties of some essential oil constituents. Lett. Appl. Microbiol. 1994, 19, 110-113. 
34. Setzer, W.N.; Schmidt, J.M.; Eiter, L.C. The leaf oil composition of Zanthoxylum fagara (L.) Sarg. from monteverde, Costa Rica, and its biological activities. J. Essent. Oil Res. 2005, 17, 333-335.

35. Moleyar, V.; Narasimham, P. Antifungal activity of some essential oil components. Food Microbiol. 1986, 3, 331-336.

36. Jiang, Z.L.; Zhang, X.; Feng, J.T. A critical review of the essential oils and its application in plant protection. J. Shaanxi Agric. Sci. 2002, 1, 32-36.

37. SAS Institute. SAS/STAT User's Guide, Version 9.1.3; SAS Institute: Cary, NC, USA, 2004.

Sample Availability: Samples of the compounds [L. petersonii oil, neral and geranial] are available from the authors.

(C) 2012 by the authors; licensee MDPI, Basel, Switzerland. This article is an open access article distributed under the terms and conditions of the Creative Commons Attribution license (http://creativecommons.org/licenses/by/3.0/). 